\title{
The Elimination by Natural Algerian Clay of Chromium Ions from Salt Water
}

\author{
Rachid Chebbi, Amar Fadel ${ }^{*}$, Amel Aidi
}

Department of Industrial Chemical, Laboratory of Industrial Chemical, Mohammed Khieder University of Biskra, Biskra 07000, Algeria

Corresponding Author Email: am.fadel@univ-biskra.dz

https://doi.org/10.18280/acsm.450202

Received: 23 November 2020

Accepted: 28 March 2021

\section{Keywords:}

adsorption, brackish water, bentonite, chromium removal, kinetic

\begin{abstract}
This paper studies the removal of chromium ions from synthetic brackish water by an adsorption method using natural Algerian Bentonite (NAB), the mineral clay was characterized through FTIR, XRD and SEM/EDS analysis. The effect of the main physicochemical parameters; namely: clay dosage, initial metal ion concentration, $\mathrm{pH}$, and contact time on the removal of $\mathrm{Cr}^{+3}$ was investigated. The results showed that equilibrium was attained within 5 minutes of stirring time. The retention capacity $\mathrm{of} \mathrm{Cr}^{+3}$ increased with the increase of adsorbent dose and decreased with the increased initial metal ion concentration. The Langmuir and Freundlich isotherm models were applied to determine the efficiency of bentonite used as an adsorbent. According to the obtained results, the Langmuir model adjusts very well to the experimental data. Based on the kinetic studies for the raw bentonite, it was verified that the mechanism corresponds to predominant pseudo-second- order adsorption.
\end{abstract}

\section{INTRODUCTION}

Chromium, one of the most common elements in the earth's crust and seawater, which exists in several oxidation states, namely as metallic $\left(\mathrm{Cr}^{0}\right)$, trivalent $(+3)$ and hexavalent $(+6)$ chromium. $\mathrm{Cr}(\mathrm{VI})$ compounds are much more soluble than $\mathrm{Cr}(\mathrm{III})$ and are much more toxic (mutagenic and carcinogenic) to microorganisms, plants, animals and humans [1, 2]. In contrast, $\mathrm{Cr}$ (III) has relatively low toxicity and is immobile under moderately alkaline to slightly acidic conditions [3]. Since chromium is widely used in industrial processes, it is becoming one of the heavy metals occurring contamination in water sources used for drinking water production, including groundwater, which affect and changing the environment [4].

Several methods for reducing heavy metals $\mathrm{Cr}$ (III), such as coagulation -precipitation, with alum and Fe (III) salts ion as coagulation and precipitation with lime, caustic soda and sodium carbonate effective for $\mathrm{Cr}$ ( III) or if they are present as anions [5, 6], ion exchange is a proven technology for small systems for the removal chromium of low concentrations by ion (cation) exchange [7, 8], and reverse osmosis technique used for removal of chromium, other heavy metals from different wastewater that excellent $\mathrm{Cr}$ (III) [9], These methods are costly or inefficient, especially when concentrations of the metal ions are less than $10 \mathrm{mg} / \mathrm{L}[10,11]$.

Adsorption is one of these methods widely available, efficiency, low cost process, that use to eliminate heavy metals at various temperature, such as $\mathrm{Cr}(\mathrm{VI}), \mathrm{Cd}(\mathrm{II}), \mathrm{Pb}$ (II), $\mathrm{Cu}$ (II) and $\mathrm{Zn}(\mathrm{II})$ and to eliminate color, smell, and materials organic compounds.

Recently, natural and activated bentonite for the adsorption of heavy metals at different temperatures have been reported such as $\mathrm{Cr}$ (VI), $\mathrm{Cd}$ (II), $\mathrm{Pb}$ (II), $\mathrm{Cu}$ (II) and $\mathrm{Zn}$ (II) in the literature [12-16]. Bentonite is highly influential for their sorptive properties, which stem from their surface area, and their tendency to absorb water in interlayer sites [17, 18], though all clay minerals have similar compositions, bentonite is superior with its unique cation chemistry and high surface area. It is mainly composed of montmorillonite with a chemical composition of $\mathrm{SiO}_{2}, \mathrm{Al}_{2} \mathrm{O}_{3}, \mathrm{CaO}, \mathrm{MgO}, \mathrm{Fe}_{2} \mathrm{O}_{3}$, $\mathrm{Na}_{2} \mathrm{O}, \mathrm{K}_{2} \mathrm{O}$ [19].

The selection of using the raw bentonite is justified by the fact that it is both a low cost and friendly environmental adsorbent material.

The objective of this study was to investigate the potential use of Algerian natural bentonite as a competitive adsorbent for the removal of chromium from aqueous solutions as the solution utilize.

Batch experiments were carried out first to determine an optimal contact time, so the influence of most important parameters such as initial concentration, $\mathrm{pH}$, the mass of the adsorbent, agitation time were being studied.

\section{MATERIALS AND METHODS}

\subsection{Bentonite}

The bentonite used and which is rich in montmorillonite was obtained from Hammam Boughrara mine (Maghnia, west Algeria). The characteristics of this sodium based bentonite which were determined by the laboratory analysis carried out by the Bentonite Unit of the National Company of non-ferrous mineral products are summarized in Table 1 . 
Table 1. Physical and chemical characteristics of natural Algerian bentonite (NAB)

\begin{tabular}{|c|c|c|c|c|c|c|}
\hline \multirow{2}{*}{ Surface area $\left(\mathrm{m}^{2} / \mathrm{g}\right)$} & \multirow{2}{*}{ Ion exchange Capacity (meq/100g) } & \multirow{2}{*}{ pH } & \multicolumn{4}{|c|}{ Exchangeable cation (meq/100g) } \\
\hline & & & $\mathrm{Ca}^{2+}$ & $\mathrm{Mg}^{2+}$ & $\mathrm{Na}^{+}$ & $\mathrm{K}^{+}$ \\
\hline 80 & 95 & 6.2 & 30.6 & 12.8 & 36.2 & 9.5 \\
\hline
\end{tabular}

\subsection{Preparation of stock solutions}

Chromium (III) dye solution were prepared using distilled water. To have a good reproducibility of the results of the adsorption studies, we prepared in a flask large volumes (1L) of stock solution $\left[\mathrm{Cr}\left(\mathrm{H}_{2} \mathrm{O}\right)_{6}\left(\mathrm{NO}_{3}\right)_{3} .3 \mathrm{H}_{2} \mathrm{O}\right.$, molecular weight: $400.21 \mathrm{~g} / \mathrm{l}]$ of dye at a concentration of $\left(1 \mathrm{gL}^{-1}\right)$ and sodium chloride $(\mathrm{NaCl})$ with a concentration of $\left(3 \mathrm{gL}^{-1}\right)$. Solutions of low concentration $(3 \mathrm{mg} / \mathrm{l}, 6 \mathrm{mg} / \mathrm{l}, 12 \mathrm{mg} / \mathrm{l}, 18 \mathrm{mg} / \mathrm{l}$ and $24 \mathrm{mg} / \mathrm{l})$ were prepared from a stock solution.

We use this Eq. (1) to decide how much stock solution we will need:

$$
\mathrm{C}_{1} \mathrm{~V}_{1}=\mathrm{C}_{2} \mathrm{~V}_{2}
$$

where,

$\mathrm{C}_{1}$ : concentration of stock solution;

$\mathrm{C}_{2}$ : Concentration you want your dilute solution to be;

$\mathrm{V}_{1}$ : how much stock solution you will need;

$\mathrm{V}_{2}$ : how much of the dilute solution you want to make.

The dye used has the property, due to its apparent color, of selectivity absorbing certain radiations of the white light spectrum. This property is used to measure the dye concentration in water. This fast and reproducible method allows immediate and reliable analysis of samples. Chromium (III) is measured by an atomic absorption spectrophotometer using a PinAAcle 900T.

Chromium (III) is determined at a wavelength equivalent to $357.9 \mathrm{~nm}$.

The calibration curve is established for a concentration range of 0 to $60 \mathrm{mg} / \mathrm{l}$ of $\mathrm{Cr}$ (III). The calibration line giving the concentration as a function of the absorbance (Figure 1).

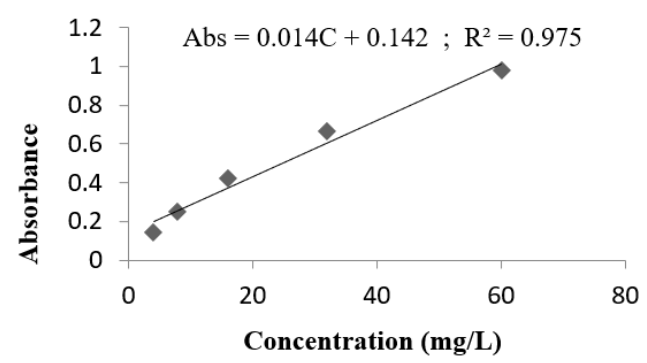

Figure 1. Chromium (III) calibration curve tested

\subsection{Equilibrium isotherms}

Batch mode adsorption tests have been performed on Chromium to examine the impact of various parameters of operation.

In Erlenmeyer, batch equilibrium tests were carried out in flash $250 \mathrm{ml}$ of $\mathrm{Cr}^{+3}$ ion solutions with different initial concentrations and the optimum adsorbent weight and optimum solution $\mathrm{pH}$ material.

The bottles were mixed for 2 hours at a fixed speed of 250 rpm in a rotating stirrer water bath.

The solutions were then filtrated, using the atomicabsorption spectrophotometer at $540 \mathrm{~nm}$ to evaluated the residual $\mathrm{Cr}^{+3}$ ion concentration in the filtrate. From the mass balance equation, the adsorption of metal ions to the adsorbent surface was measured at a specific time [20].

The quantity of chromium adsorbed by a unit of bentonite mass was measured using the formula below (2):

$$
q t=\frac{(\text { Co }- \text { Ce }) \times V}{m}
$$

where, $\mathrm{q}_{\mathrm{t}}, \mathrm{C}_{0}, \mathrm{C}_{\mathrm{e}}, \mathrm{v}$ and $\mathrm{m}$ are: the amount adsorbed at time $\mathrm{t}(\mathrm{mg} / \mathrm{g})$ initial metal ion concentration $(\mathrm{mg} / \mathrm{L})$, equilibrium metal ion concentration $(\mathrm{mg} / \mathrm{L})$, volume of the solution $(\mathrm{L})$ and mass of the adsorbent $(\mathrm{g})$, respectively.

The results may be expressed in percentage removal as given by the following formula (3).

As given by the following formula (3), the results can be expressed in the percentage removal [21, 22].

$$
\mathbf{E}(\%)=\frac{(\mathbf{C o}-\mathbf{C e})}{\text { Co }} \times 100
$$

\section{RESULTS AND DISCUSSION}

It is necessary to differentiate between the various components of clay mineral mixtures and to obtain information on their structure, composition and structural changes before testing the bentonite. For this reason, natural Algerian Bentonite (NAB) samples were passed to different techniques analysis as FTIR, XRD, and EDS for bentonite characterization.

\subsection{FTIR analysis of natural Algerian bentonite}

The study of raw bentonite by Fourier transform infrared spectroscopy (FTIR) was conducted out in the range of 400$4000 \mathrm{~cm}^{-1}$ (Figure 2).

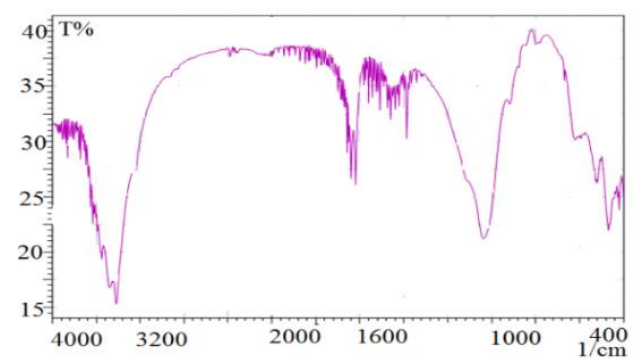

(A)

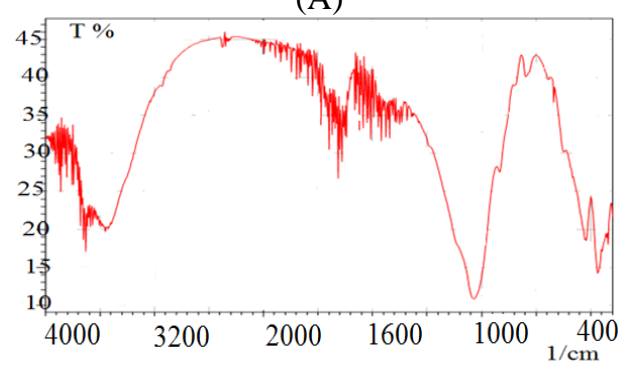

(B)

Figure 2. FTIR spectra of (A) natural Algerian bentonite and (B) after adsorption 
Vibrations of the $\mathrm{OH}$ groups for the water molecules adsorbed on the bentonite surface are responsible for the absorption bands of raw bentonite at $3627.60 \mathrm{~cm}^{-1}$. The band at $3411 \mathrm{~cm}^{-1}$ is due to $\mathrm{OH}^{-}$vibration of physically adsorbed water. The bending vibration mode of water is $1627 \mathrm{~cm}^{-1}$. The stretching vibration of the $\mathrm{Si}-\mathrm{O}$ bands is attributed to the 1035 $\mathrm{cm}^{-1}$ band, and the $912 \mathrm{~cm}^{-1}$ band has been found to relate to the Al-Al-OH bending frequencies for $835 \mathrm{~cm}^{-1}$, the Al-Mg$\mathrm{OH}$ bending vibrations were noted. The bands at 443 and 509 $\mathrm{cm}^{-1}$ relate to $\mathrm{Al}-\mathrm{O}-\mathrm{Si}$ and $\mathrm{Si}-\mathrm{O}-\mathrm{Si}$ bending vibrations, respectively.

In addition, the raw bentonite after adsorption (NAB-Cr(III)) sample spectrum shows that no structural change was observed in the clay sample after chromium adsorption , and only peak shifts and peak intensity changes were observed, there are many impurities for example chromium oxides and argillaceous complexes after adsorption.

\subsection{XRD analysis}

The X-ray diffraction (XRD) analysis for natural Algerian bentonite was used to identify the bentonite structure. Figure 3 shows the XRD spectrum for the natural Algerian bentonite before, and after adsorption.

The analysis of the spectrum of the raw bentonite used illustrates the following characteristic peaks: Quartz $(2 \Theta=26.34)$, montmorillonite $(2 \Theta=23.67,2 \Theta=19.88)$, illite $(2 \Theta=37)$.

The XRD pattern of natural Algerian bentonite charged by chrome after adsorption demonstrate the apparition of peaks related different crystalline chromium oxides $(2 \theta=53,2 \Theta=58$, $2 \Theta=68,2 \Theta=78)$.

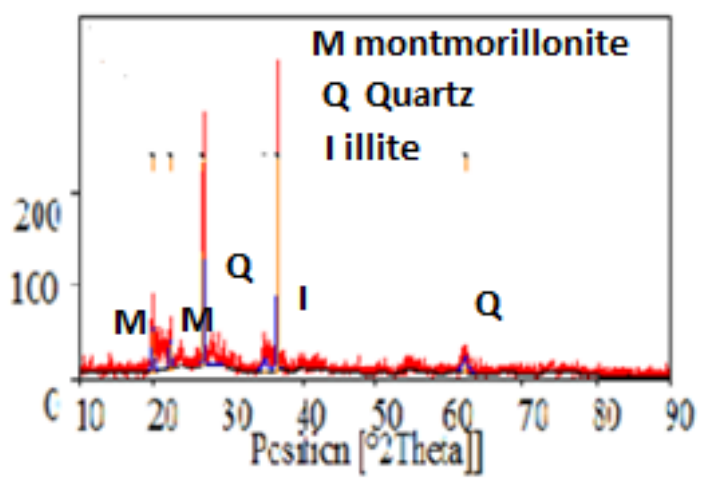

(A)

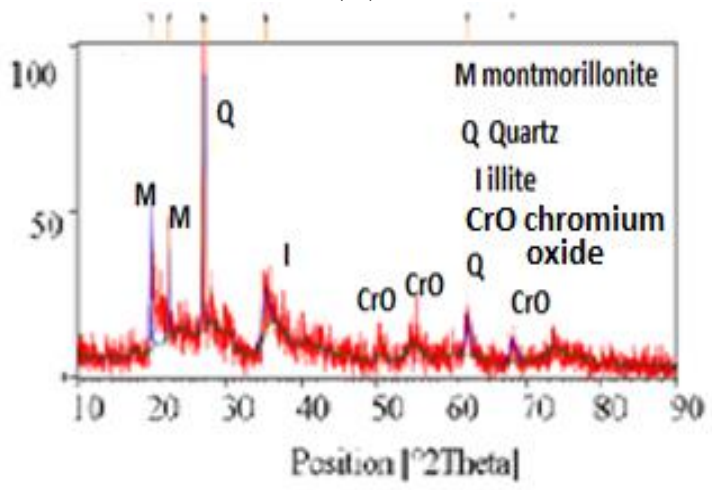

(B)

Figure 3. XRD pattern of (A) natural Algerian bentonite and (B) after adsorption

\subsection{MEB/EDX analysis of natural Algerian bentonite}

The morphological analysis and elemental analysis of raw bentonite was prepared using an energy dispersive spectrometer (SEM/ EDX) scanning electron microscope.

Table 2. Elemental of analysis of natural Algerian bentonite

\begin{tabular}{ccc}
\hline Element & Weight \% & Atomic \% \\
\hline $\mathrm{O}$ & 49.89 & 58.88 \\
$\mathrm{Si}$ & 15.19 & 10.22 \\
$\mathrm{C}$ & 11.77 & 18.50 \\
$\mathrm{Ca}$ & 9.23 & 4.35 \\
$\mathrm{Al}$ & 6.65 & 4.65 \\
$\mathrm{Fe}$ & 4.05 & 1.37 \\
$\mathrm{~K}$ & 1.57 & 0.76 \\
$\mathrm{Mg}$ & 1.34 & 1.04 \\
$\mathrm{Na}$ & 0.26 & 0.21 \\
$\mathrm{Cu}$ & 0.05 & 0.02 \\
\hline
\end{tabular}

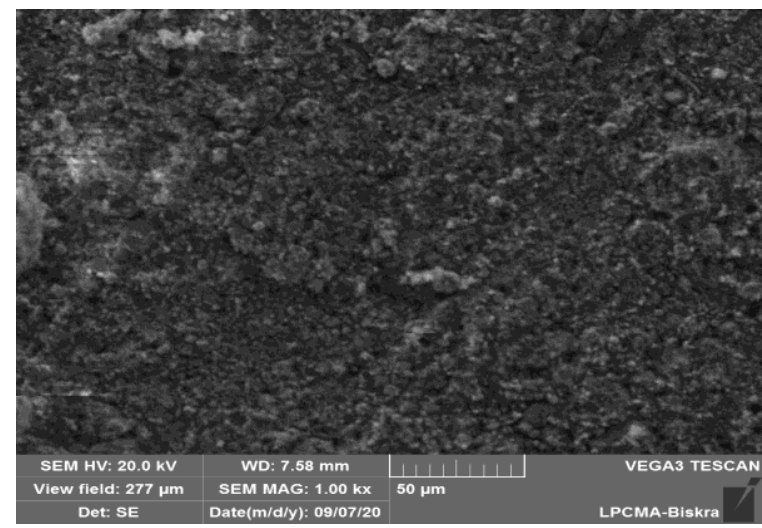

(A)

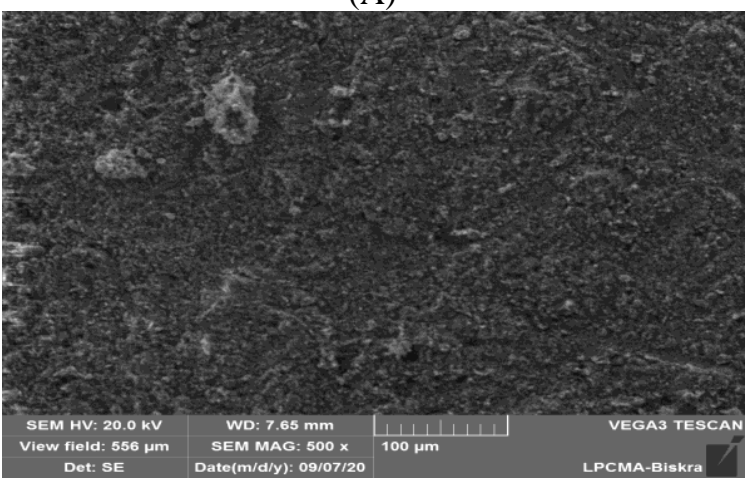

(B)

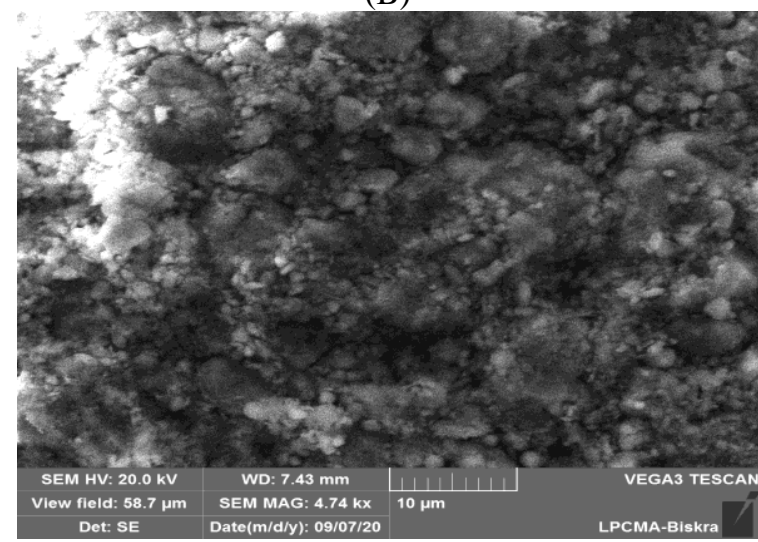

(C)

Figure 4. SEM images of the natural Algerian Bentonite (A magnification: $\times 4.74 \mathrm{k}, \mathrm{B}$ magnification: $\times 1.00 \mathrm{k}, \mathrm{C}$ magnification: $\times 500$ ) 
To analyse the texture of the clay sample and to classify mineralogical assemblages, scanning electron microscopy (SEM) is used the Figure 4 obtained by scanning electron microscopy of the clay sample.

The findings of the scanning electron microscopy (SEM) study have shown that there is a morphological structure of natural Algerian bentonite in aggregates and in non-uniform surfaces.

The EDX analysis indicated that oxygen (49.89\%) and silicon (15.19\%) were major composition of natural bentonite (Table 2). In addition, $\mathrm{C}(11.77 \%), \mathrm{Ca}$ (9.23), $\mathrm{Al}$ (6.65), Fe (4.05), K (1.57), $\mathrm{Mg}(1.34 \%), \mathrm{Na}(0.26 \%)$ and $\mathrm{Cu}(0.05 \%)$.

\section{$3.4 \mathrm{pH}$ point of zero charges ( $\mathrm{pH} \mathrm{PZC})$}

The experimental protocol for determining the $\mathrm{pH}$ point of zero charge is as follows:

$50 \mathrm{mg}$ of the adsorbent is added to $50 \mathrm{ml}$ of water at different $\mathrm{pH}$ ranging from 2 to 12 , the $\mathrm{pH}$ adjusted by adding $\mathrm{HCl}$ or $\mathrm{NaOH}$ to $0.01 \mathrm{M}$. The adsorbent mass is agitated for 24 hours.

Based on Figure 5, there is a quasi-stability of the final $\mathrm{pH}$, in the initial $\mathrm{pH}$ range of 5 to 8 , so the bearing formed by this constancy of the final $\mathrm{pH}$ can be related to the surface charge transfer, of the adsorbent from positive to negative and vice versa, $\mathrm{pH}_{\mathrm{pzc}}$ value found in this raw bentonite equal $6.4 \pm 0.1$.

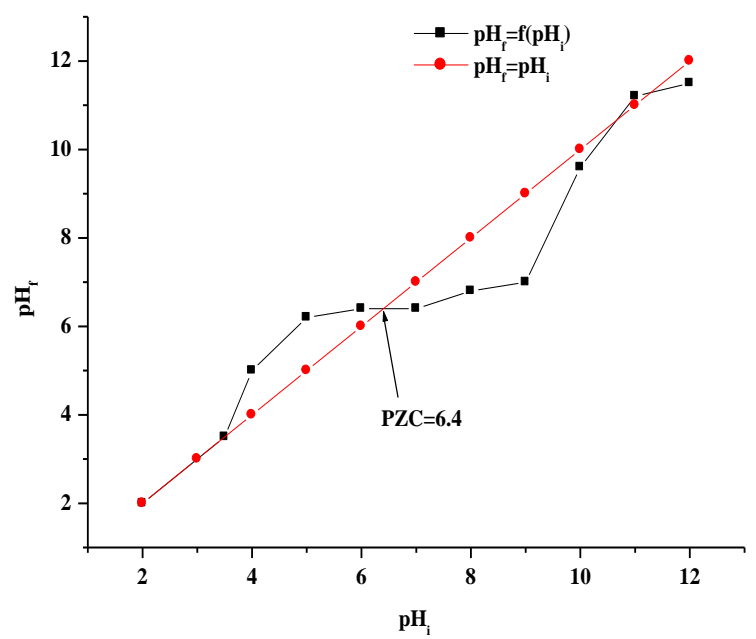

Figure 5. $\mathrm{pH}$ point of zero charges ( $\mathrm{pH} \mathrm{PZC})$

\subsection{The effect of the physicochemical parameters}

The study of the adsorption of $\mathrm{Cr}^{+3}$ ions on natural bentonite requires knowledge of the parameters that influence this phenomenon, namely: Initial concentration, adsorbent dosage, $\mathrm{pH}$, stirring time.

\subsubsection{Influence of the initial concentration of $\mathrm{Cr}^{+3}$}

We carried out this experiment for initial concentration $\mathrm{Cr}^{+3}$ ranging from 3 to $24 \mathrm{mg} / 1$. The dose of the introduced bentonite is $1 \mathrm{~g} / 1, \mathrm{pH}=4.0$ and temperature $=18^{\circ} \mathrm{C}$.

According to the results presented in Figure 6, we can see an increase in adsorption efficiency then a gradual decrease with the increase of the initial content of $\mathrm{Cr}^{+3}$, the increase of the initial trivalent chromium concentration would increase the driving force of mass transfer and thus the rate at which trivalent chromium ions move from the solution phase to the carbon surface.
The gradual decreasing explained of the saturation of active sites of the adsorbent.

In sodium chloride solution (salt water) the rate and capacity of trivalent chromium adsorption by natural bentonite are better compared to those obtained in the absence of $\mathrm{NaCl}$.

This can be explained by the activation by $\mathrm{Na}^{+}$ions of the sites of bentonite adsorption where new sites of adsorption would be created [14]. With the initial concentration growing of $\mathrm{Cr}^{+3}$, this effect is intensified. It can be established that with the increase in the concentration of $\mathrm{NaCl}$ (ionic solution strength), the adsorption efficiency increases.

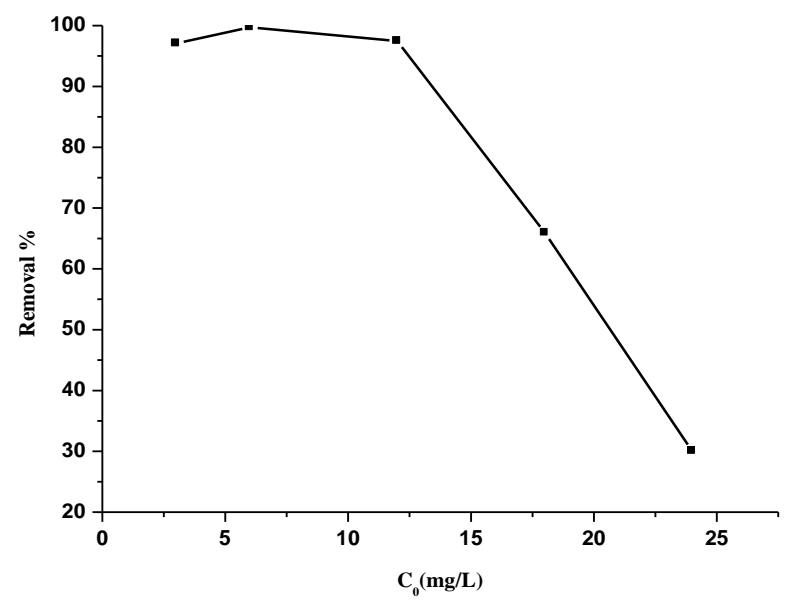

Figure 6. The effect of the initial concentration of $\mathrm{Cr}^{+3}$ on the adsorption performance $\left(\mathrm{m}=1 \mathrm{~g} / \mathrm{L}, \mathrm{pH}=4, \mathrm{~T}=18^{\circ} \mathrm{C}\right.$, agitation time $=2 \mathrm{~h}$ )

\subsubsection{Effect of dosage of adsorbent}

Figure 7 demonstrates the influence of the natural bentonite dosage on the adsorption mechanism.

Adsorption performance of different raw bentonite weights $(25,125,250,375,500,750 \mathrm{mg})$ combined with $250 \mathrm{ml}$ of chromium solution at $\mathrm{pH}=4$.

The consequence shows that the efficiency of adsorption increases slightly with bentonite dose before balance is achieved.

The improvement in the effectiveness of adsorption can be attributed to the increased abundance on the adsorbent surface of the number of active sites.

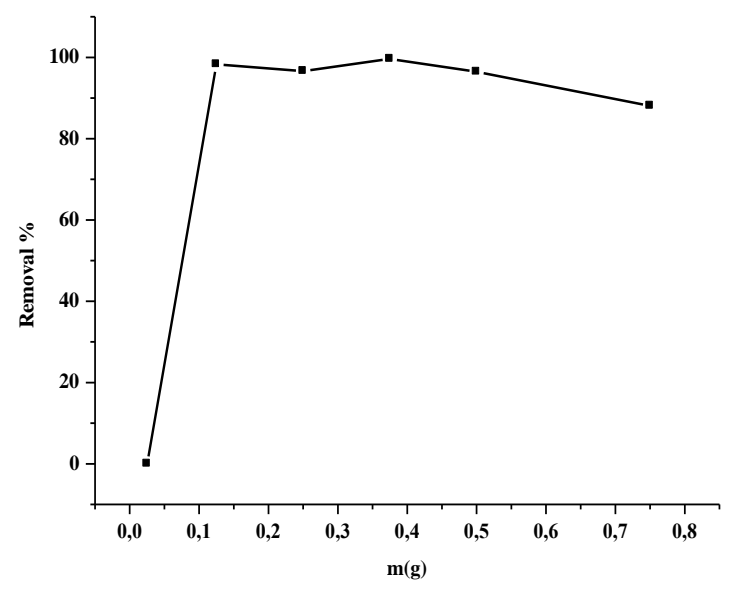

Figure 7. The influence of the amount of adsorbent on the efficiency of adsorption

$\left(\mathrm{C}_{0}=6 \mathrm{mg} / \mathrm{L}, \mathrm{pH}=4, \mathrm{~T}=18^{\circ} \mathrm{C}\right.$, agitation time $\left.=2 \mathrm{~h}\right)$ 
At a bentonite dosage of $375 \mathrm{mg}$, the complete elimination occurs. After that, while any adsorbent has a finite number of active sites that are saturated with of active sites that are saturated with $\mathrm{Cr}^{3+}$ over time, adsorption is steady.

\subsubsection{Effect of $\mathrm{pH}$ and adsorption mechanism}

By varying the $\mathrm{pH}$ from 3 to 12 , the effect of $\mathrm{pH}$ on the adsorption of $\mathrm{Cr}^{3+}$ ions were investigated. The adsorption percentage for raw bentonite rises in $\mathrm{pH}$ (3-6) is shown in Figure 8, It appears that the elimination rate of chromium ions is affected by the surface charges of the adsorbent, which are variable depending on the $\mathrm{pH}$. For natural Algerian Bentonite (NAB) the highest efficiency $(99.63 \%)$ was obtained at a $\mathrm{pH}$ equal 6 , this related to a decrease in competitiveness between $\mathrm{H}^{+}$and $\mathrm{Cr}^{+3}$ and reduction in positive surface charge between the surface of bentonite particles and $\mathrm{Cr}^{+3}$ ions, the electrical charge is lower.

The slight reduction in the ability to remove $\mathrm{Cr}^{+3}$ ions at $\mathrm{pH}>6$ may be due to the development of complexes between $\mathrm{Cr}^{+}$and $\mathrm{OH}^{-}$.

This hydroxyl chrome will take part in adsorption and precipate into the raw bentonite structure.

Adsorption and ion exchange are the fundamental mechanism. That control the adsorption characteristics of bentonite at $\mathrm{pH}$ ranging from 3 to 6 . At these $\mathrm{pH}$ levels, exchangeable cations present at exchangeable sites $\left(\mathrm{Na}^{+}, \mathrm{K}^{+}\right.$, $\mathrm{Ca}^{2+}$ and $\mathrm{Mg}^{+2}$ are exchanged for $\mathrm{Cr}{ }^{+3}$ cations in aqueous solutions.

Several authors have mentioned the following mechanism for the adsorption of heavy metals at negative bentonite sites [23].

$$
\begin{gathered}
M^{+n}+\mathrm{H}_{2} \mathrm{O} \leftrightarrow \mathrm{MOH}^{+}+(n-1) H^{+} \\
\mathrm{MOH}^{+}+X^{-} \leftrightarrow X M O H
\end{gathered}
$$

As shown in Eqns. (6) and (7) below the solution will cause the surface functional groups on clay particles to protonate and deprotonate by adsorption of $\mathrm{OH}^{-}$or $\mathrm{H}^{+}$ions, respectively:

$$
\begin{gathered}
\mathrm{XOH}+\mathrm{H}^{+} \leftrightarrow \mathrm{X}-\mathrm{OH}_{2}^{+} \\
\mathrm{XOH} \leftrightarrow \mathrm{X}-\mathrm{O}^{-}+\mathrm{H}^{+}
\end{gathered}
$$

$\mathbf{X}$ : surface of bentonite; $\mathbf{M}$ : metal, in our study $\mathbf{M}$ is the chrome $(\mathrm{Cr})$.

The $\mathrm{pH}$ effect on the chromium ions adsorption by raw bentonite (NAB) can be explained on the basis of $\mathrm{pHpzc}$, for which the charge of the adsorbent surface is positive lower than $\mathrm{pHpzc}$ of bentonite $(\mathrm{pHpzc}=6.4 \pm 0.1)$. As the $\mathrm{pH}$ increase, the number of negatively charged sites augments and improves the chromium ions adsorption by electrostatic attractions.

The degradation of $\mathrm{Cr}(\mathrm{III})$ at $\mathrm{pH}$ above $\mathrm{pH} \mathrm{PZC}$ is enhanced by the modifying the surface metal complexes in the ionized silanol and aluminol ( $\mathrm{Si}-\mathrm{O}$-and $\mathrm{Al}-$ ) groups, the complex $\mathrm{Cr}^{+3}$ reaction , and $\mathrm{Cr}(\mathrm{OH})_{3}$.

When $\mathrm{Cr}$ (VI) Oxyanions in solution are in contact with certain functions (-COOH,- $\mathrm{OH})$ on the adsorption sites, they are typically minimized by specific reduction to less toxic $\mathrm{Cr}$ (III) cations[17], and raw bentonite has effectively adsorbed the lowered $\mathrm{Cr}(\mathrm{III})$.

As $\mathrm{Cr}$ (III) is insoluble at neutral and basic $\mathrm{pH}$, its elimination is rather simple compared to $\mathrm{Cr}$ (VI) removal. Therefore, the removal or reduction of $\mathrm{Cr}$ (VI) to $\mathrm{Cr}$ (III) present as a key method for removal of $\mathrm{Cr}$ (VI) polluted water and waste water [24].

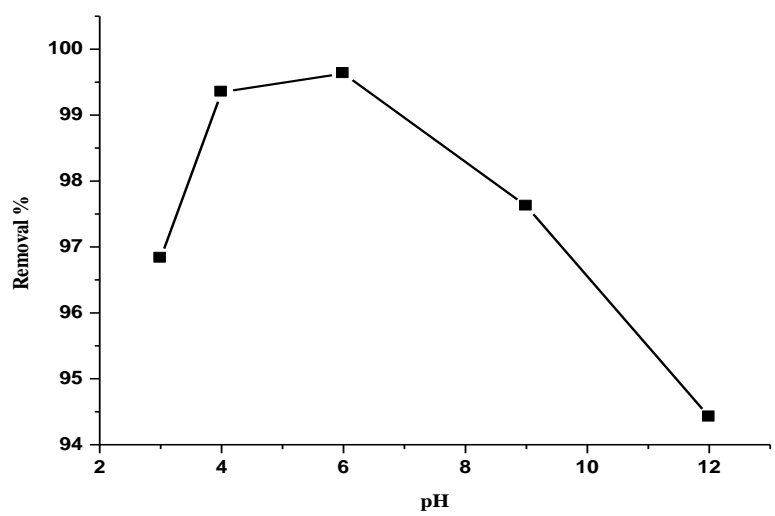

Figure 8. The effect of $\mathrm{pH}$ on adsorption of $\mathrm{Cr}^{+3}$ on the adsorption performance $\left(\mathrm{m}=1 \mathrm{~g} / \mathrm{L}, \mathrm{C}_{0}=6 \mathrm{mg} / \mathrm{L}, \mathrm{T}=18^{\circ} \mathrm{C}\right.$, agitation time $=2 \mathrm{~h}$ )

\subsubsection{Effect of agitation time}

We followed the adsorption kinetics of $\mathrm{Cr}^{+3}$ for an initial chromium content equal to $6 \mathrm{mg} / \mathrm{l}$, a constant dosage of the adsorbent $(1 \mathrm{~g} / \mathrm{l}), \mathrm{pH}=4$ and temperature is $18.8^{\circ} \mathrm{C}$. the results obtained (Figure 9) show that the removal efficiency of $\mathrm{Cr}^{+3}$ varies with the stirring time, after 5 minutes, the maximum efficiency was achieved.

Indeed, for different stirring speeds (50, 150 and $250 \mathrm{rpm})$, the maximum value corresponding to the removal at this time is $92 \%$, after which the adsorption rate becomes basically very slow.

The difference in the degree of adsorption may well be due to the fact that at the beginning of adsorption, all the sites on the surface of the adsorbent are free and the concentration gradient of the solute is extremely high.

Furthermore, the degree of removal of $\mathrm{Cr}^{+3}$ decreased with the increase in contact time, which refers to the number of vacant sites on the bentonite surface.

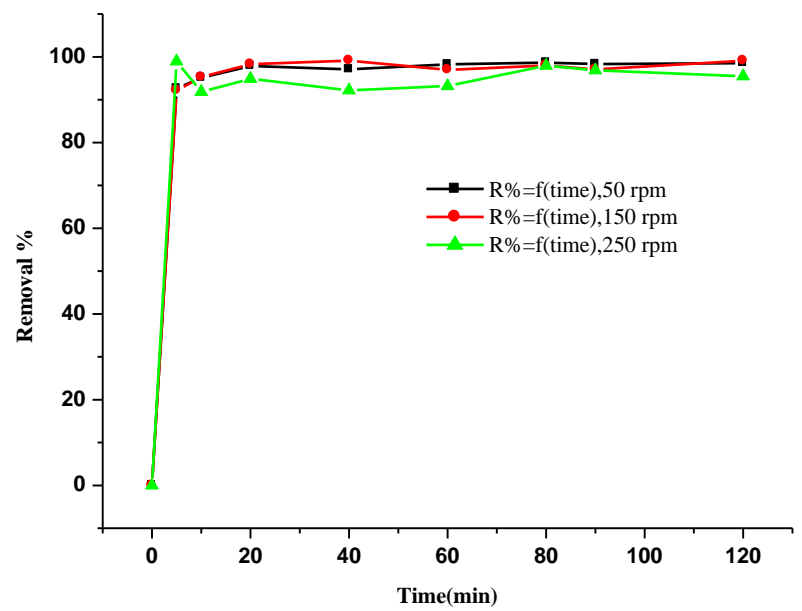

Figure 9. The effect of agitation time of $\mathrm{Cr}^{+3}$ on the adsorption performance $\left(\mathrm{C}_{0}=6 \mathrm{mg} / \mathrm{L}, \mathrm{pH}=4, \mathrm{~T}=18^{\circ} \mathrm{C}\right)$

\subsection{Adsorption isotherms of chrome ions on the bentonite}

For the removal of $\mathrm{Cr}^{+3}$ on bentonite, the Langmuir and Freundlich adsorption isotherms using linear forms were also used as follows [25, 26]. 
Langmuir linear form:

$$
\frac{1}{q}=\frac{1}{q m b C e}+\frac{1}{q m}
$$

where, $\mathrm{Ce}$ is the equilibrium concentration in $(\mathrm{mg} / \mathrm{l}), \mathrm{qm}$ is the adsorption capacity calculation of the adsorbent $(\mathrm{mg} / \mathrm{g})$ and $\mathrm{b}$ is the Langmuir constant, which is the adsorption energy calculation $(1 / \mathrm{mg})$.

Freundlich linear form:

$$
\operatorname{Ln} q e=\operatorname{Ln} k+\left(\frac{1}{n}\right) \operatorname{LnCe}
$$

where, $\mathrm{C}_{\mathrm{e}}$ is the concentration of equilibrium in $(\mathrm{mg} / \mathrm{l})$, qe is the amount of equilibrium adsorbed in $(\mathrm{mg} / \mathrm{g}), \mathrm{K}$ and $1 / \mathrm{n}$ are constants of Freundlich, respectively.

Considering the following operating conditions, we used the results according to the Freundlich and Langmuir model's linear form. The initial chromium concentration is $6 \mathrm{mg} / \mathrm{l}$, the bentonite mass used is $1 \mathrm{~g} / \mathrm{l}$, the stirring speed is $250 \mathrm{rpm}, \mathrm{pH}=4$, the contact time is 2 hours, and the temperature is $18^{\circ} \mathrm{C}$.

The curves obtained with a better correlation coefficient showed that it can be estimated from our experimental conditions based on the correlation coefficient $\mathrm{R}^{2}$ (Table 3 ) that the Langmuir model is particularly suitable to the experimental data than the Freundlich model (Figure 10).

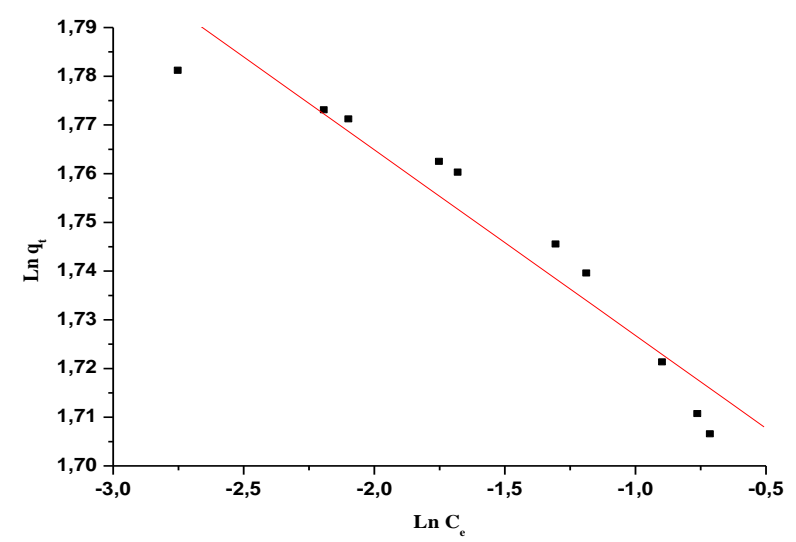

(A)



(B)

Figure 10. Linear transformation of the adsorption Isotherm using (A) the Freundlich model, (B) The Langmuir model
Table 3. Values of the coefficients of the two linearized kinetic models with experimental results

\begin{tabular}{cccccccc}
\hline \multicolumn{3}{c}{ Langmuir } & \multicolumn{4}{c}{ Freundlich } \\
\hline $\mathrm{q}_{\mathrm{m}}(\mathrm{mg} / \mathrm{g})$ & $\begin{array}{c}\mathrm{b} \\
(\mathrm{L} / \mathrm{mg})\end{array}$ & $\mathrm{R}_{\mathrm{L}}$ & $\mathrm{R}^{2}$ & $\mathrm{n}$ & $\begin{array}{c}\mathrm{K} \\
(\mathrm{mg} / \mathrm{g})\end{array}$ & $\mathrm{R}^{2}$ \\
\hline 5.46 & 183.15 & 0.0009 & 0.999 & -33.33 & 5.47 & 0.881 \\
\hline
\end{tabular}

\subsection{Chrome adsorption kinetics}

To determine the constants of adsorption rate, kinetic data were analysed using two kinetic models [27-29] namely: the model of Lagergren pseudo-first-order which is expressed as in Eq. (10):

$$
\log \frac{q e-q t}{q e}=-\frac{K_{1} \cdot t}{2.3}
$$

And the pseudo-second- order model which is expressed as in Eq. (11):

$$
\frac{t}{q t}=\frac{1}{2 K_{2} \mathrm{qe}^{2}}+\frac{t}{q e}
$$

The most typical data model was chosen on the basis of the coefficient of correlation $\mathrm{R}^{2}$, as shown in (Table 4) and (Figure 11).

Accordingly, the pseudo-second-order kinetic model is very appropriate for bentonite adsorption of chromium ions.

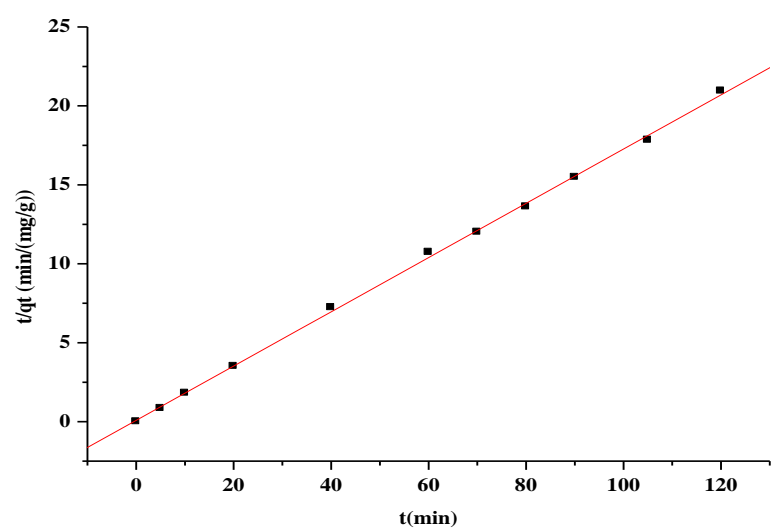

Figure 11. Kinetics of the pseudo-second order

Table 4. Values of the coefficients of the two linearized kinetic models with experimental results

\begin{tabular}{ccccccc}
\hline \multicolumn{2}{c}{$\begin{array}{c}\text { Kinetics of the pseudo } \\
\text { first order }\end{array}$} & \multicolumn{4}{c}{$\begin{array}{c}\text { Kinetics of the pseudo-second } \\
\text { order }\end{array}$} \\
\hline $\mathrm{q}_{\mathrm{e}}$ & $\mathrm{K}_{1}$ & $\mathrm{R}^{2}$ & $\mathrm{q}_{\mathrm{e} \text { cal }}$ & $\mathrm{K}_{2}$ & $\mathrm{~h}$ & $\mathrm{R}^{2}$ \\
\hline- & - & 0.044 & 5.84 & 0.0034 & 0.116 & 0.999 \\
\hline
\end{tabular}

\subsection{Comparison with various adsorbents in the literature}

In order to give reason for the validity of the Natural Algerian bentonite (NAB) as a successful adsorbent for chromium ions charged in salt water, we compared our consequences with other works published elsewhere using different adsorbents and Table 5 gives a summary of maximum adsorption capacities of NAB on $\mathrm{Cr}$ (III) compared to different adsorbents. 
Table 5 shows better value for (NAB) bentonite on $\mathrm{Cr}$ (III) adsorption, which the adsorption capacity is $5.46\left(\mathrm{mg}^{-1} \mathrm{~g}^{-1}\right)$ and the other adsorbents have the values $0.53\left(\mathrm{mg}^{-1} \mathrm{~g}^{-1}\right), 0.73$ $\left(\mathrm{mg} \cdot \mathrm{g}^{-1}\right)$ for natural sepiolite and Kaolinite respectively.

Table 5. Adsorption capacity of $\mathrm{Cr}(\mathrm{III})$ by various adsorbents

\begin{tabular}{cccc}
\hline Adsorbent & $\begin{array}{c}\text { Heavy } \\
\text { metal }\end{array}$ & $\begin{array}{c}\text { maximum } \\
\text { adsorption } \\
\text { capacities }\end{array}$ & reference \\
\hline $\begin{array}{c}\text { Natural } \\
\text { sepiolite }\end{array}$ & $\mathrm{Cr}^{+3}$ & $\begin{array}{c}\mathrm{Q}_{\mathrm{m}}(\mathrm{meg} / \mathrm{g}) \\
0.53\end{array}$ & {$[30]$} \\
Kaolinite & $\mathrm{Cr}^{+3}$ & $\begin{array}{c}\mathrm{Q}_{\mathrm{m}}(\mathrm{mg} / \mathrm{g}) \\
0.73\end{array}$ & {$[31]$} \\
$\begin{array}{c}\text { Bentonite } \\
\text { GMZ }\end{array}$ & $\mathrm{Cr}^{+3}$ & $\begin{array}{c}0.7 \mathrm{mg} / \mathrm{g}) \\
4.68\end{array}$ & {$[32]$} \\
$\begin{array}{c}\text { Bentonite } \\
\text { (NAB) }\end{array}$ & $\mathrm{Cr}^{+3}$ & $\begin{array}{c}\mathrm{Q}(\mathrm{mg} / \mathrm{g}) \\
5.46\end{array}$ & $\begin{array}{c}\text { This } \\
\text { study }\end{array}$ \\
\hline
\end{tabular}

\section{CONCLUSIONS}

Batch adsorption experiments were conducted using natural Algerian Bentonite for the removal of $\mathrm{Cr}^{+3}$ from salt water and the findings obtained could also be summarized as follows:

Efficiency of removal of chromium ions increases with increases in the introduced mass of adsorbent, when the optimum dose (1.5 g/l) exceeds output (99.33\%) and decreases progressively with the initial concentration of chromium rising.

The best performance at $\mathrm{pH} 4$ and 6 , with an elimination rate adequate to $100 \%$ and the dominant mechanism for the adsorption of trivalent chromium ions in salt water is cation exchange, the results of the adsorption kinetics confirm that the adsorption is fast and maximum efficiency (98.38\%) reached after 5 minutes of adsorption.

The Langmuir equation has well defined equilibrium isotherms giving a maximum adsorption capacity of $5.46 \mathrm{mg} /$ $\mathrm{g}$ at $18^{\circ} \mathrm{C}$. The adsorption kinetics can be well described by the equation of the pseudo-second - order model.

Ion exchange, complex formation, and surface adsorption mechanism play an essential function in the adsorption method of natural Algerian bentonite (NAB).

\section{ACKNOWLEDGMENT}

The authors would like to acknowledge University of Mohammed khieder Biskra, for financial and instrumental supports.

\section{REFERENCES}

[1] Cefalu, W.T., Hu, F.B. (2004). Role of chromium in human health and in diabetes. Diabetes Care, 27(11): 2741-2751. https://doi.org/10.2337/diacare.27.11.2741

[2] Singh, R., Mondal, M.K. (2012). Kinetics thermodynamic and equilibrium study of $\mathrm{Cr}$ (VI) adsorption from aqueous solutions by NCL. Korean Journal of Chemical Engineering, 29(1): 1782-1787. https://doi.org/10.1007/s11814-012-0092-2

[3] Zouboulis, A.I., Kydrosk, K.A., Matis, K.A. (1995). Removal of hexavalent Chromium anions from solutions by pyrite fines. Water Research, 29(7): 1755-1760. https://doi.org/10.1016/0043-1354(94)00319-3
[4] Saroj, K.S., Braislav, P., Gary, A. (2008). Chromium removal from water: a review. Journal of Water Supply: Research and Technology-Aqua, 57(8): 541-553. https://doi.org/10.2166/aqua.2008.080

[5] Beszedits, S. (1988). Chromium Removal from Industrial Wastewaters. In: J. O. Nriagu and E. Nieboer, Eds., Chromium in the Natural and Human Environments, John Wiley, New York, 232-263.

[6] Calder, L.M. (1988). Chromium contamination of groundwater. Advances in Environmental Science and Technology, 20: 215-229.

[7] Sengupta, A.K., Clifford, D. (1986). Important process variables in chromate ion exchange. Environmental Science \& Technology, 20(2): 149-155. https://doi.org/10.1021/es00144a006

[8] Berta, G., David, C., Inmacula, O. (2005). Removal and recovery of $\mathrm{Cr}$ (VI) from polluted ground waters: A comparative study of ion-exchange technologies. Water Research, 39(18): 4317-24. https://doi.org/10.1016/j.watres.2005.08.015

[9] Gunatilake, S.K. (2015). Methods of removing heavy metals from industrial wastewater. Journal of Multidisciplinary Engineering Science and Technology, 1(1): 12-18.

[10] Fu, F.L., Wang, Q. (2011). Removal of heavy metal ions from wastewaters: A review. Journal of Environmental Management, 92(3): 407-418. https://doi.org/10.1016/j.jenvman.2010.11.011

[11] Mahmous, T., Malik, S.A., Hussain, S.T. (2010). Biosorption and recovery of heavy metals from aqueous solution by Eichhornia crassipes (water hyacinth) ASH. Bioresources, 5(2): 1244-1256.

[12] Rauf, M., Iqbal, J., Ikram, M., Rauf, N. (2003). Adsorption studies of $\mathrm{Ni}$ (II) from aqueous solution onto bentonite. Journal of Trace and Microprobe Techniques, 21(2): 337-342. https://doi.org/10.1081/TMA120020267

[13] Koyuncu, M. (2012). Adsorption of Cr (VI) From textile waste water by using natural bentonite. IIOAB Journal, 3(3): 1-4.

[14] Fadel, A., Nacef, S. (2017). Examination of an Algeria clay in the retention of Zinc ions charged in brackish water. Korean Chemical Engineering Research Journal, 55(5): 685-689. https://doi/10.9713/kcer.2017.55.5.685

[15] Ouakouak, A., Rihani, A., Youcef, L., Hamdi, N., Guergazi, S. (2020). Adsorption characteristics of $\mathrm{Cu}$ (II) onto $\mathrm{CaCl}_{2}$ pretrated Algerian bentonite. Material Research $\quad$ Express, $\quad 7(2)$ : $1-9$. https://doi.org/10.1088/2053-1591/ab5ee4

[16] Kim, T.K., Park, S., Cho, S.Y., Kim, H.B., Kang, Y., Kim, S.D., Kim, S.J. (2005). Adsorption of heavy metals by brewery biomass. Korean Journal of Chemical Engineering, 22(1): 91-98. https://doi.org/10.1007/BF02701468

[17] Sirirak, J., Worawannotal, N., Suwanchawalit, C., Chayabutra, S. (2020). Preparation and characterization of lake pigments from sappan wood using Thai local clays. Journal of Metals, Materials and Minerals, 30(1): 20-28. https://doi.org/10.14456/jmmm.2020.3

[18] Rao, B., Mohan, Rao, V.V. (2015). Thermodynamic and isothermal studies of congo red adsorption onto modified bentonite. Korean Chemical Engineering Research Journal, 53(6): 770-775. https://dx.doi.org/10.9713/Kcer.2015.53.6.1 
[19] Onal, M. (2006). Physicochimical properties of bentonites: An averview. Communications Faculty of Sciences University of Ankara Series B, 52(2): 7-21.

[20] Grassi, M., Kaykioglu, G., Belgiorno, V., Lofrano, G., (2012). Removal of Emerging Contaminants from Water and Wastewater by Adsorption Process. Springer, New York.

[21] Oliveria, E.A., Montanher, S.F., Andrader, A.D., Nobrega, J.A., Rollemberg, M.C. (2005). Equilibrium studies for the sorption of chromium and nickel from aqueous solution using rice bran. Process Biochemistry, 40(11): $3485-3490$ https://doi.org/10.1016/j.procbio.2005.02.026

[22] Bastan, T., Tabatabai, M.A. (1992). Effect of cropping systems on adsorption of metals by soils. Soil Sciences, 331-337.

[23] Boukerroui, A., Ouali, M. (2001). Activation of a bentonite by an ammonium salt; evolution of the exchange capacity and of the specific surface area. Annales de Chimie Science des Matériaux, 25(7): 583590. https://doi.org/10.1016/S0151-9107(01)80013-1

[24] Vo, A.T., Nguyren, V.P., Ouakouak, A., Nieva, A., Doma Jr, B.T., Tran, H.N., Chao, H.P. (2019). Efficient removal of $\mathrm{Cr}$ (VI) from water by biochar and activated carbon prepared through hydrothermal carbonization and pyrolysis: Adsorption-coupled reduction mechanism. Water Journal, 11(6): 1-14. https://doi:10.3390/w11061164

[25] Sharma, S.K., Petrusevski, B., Amy, G. (2008) Chromium removal from water. Journal of Water Supply: Research and Technology, 57(8): 541-553. https://doi.org/10.2166/aqua.2008.080

[26] Ho, Y.S., McKay, G. (1998). Comparison of chemisorption kinetic models applied to pollutant removal on various sorbents. Process Safety and Environment Protection, 76(4): 332-340. https://doi.org/10.1205/095758298529696

[27] Mohammed-Azizi, F., Dib, S., Boufatit, M. (2013). Removal of heavy metals from aqueous solutions by Algerian bentonite. Desalination and Water Treatment, 51(22-24): $4447-4458$ https://doi.org/10.1080/19443994.2013.770241

[28] Bhattacharyya, K.G., Gupta, S.S. (2008). Adsorption of a few heavy metals on natural and modified kaolinite and montmorillonite. Advences in Colloid and Interface Science, 140(2): 114-131. https://doi.org/10.1016/j.cis.2007.12.008
[29] Foo, K.Y., Hameed, B.H. (2010). Insights into the modeling of adsorption isotherm systems. Chemical Engineering Journal, 156(1): 2-10. https://doi.org/10.1016/j.cej.2009.09.013

[30] Kocaoba, S. (2009). Adsorption of Cd (II), Cr (III) and Mn (II) on natural sepiolite. Desalination, 244(1-3): 2430. https://doi.org/10.1016/j.desal.2008.04.033

[31] Chantawong, V., Harvey, N., Bashkin, V. (2003). comparison of heavy metal adsorption by Thai kaolin and ballclay. Water Air Soil Pollution, 148(1): 111-125. https://doi.org/10.1023/A:1025401927023

[32] Chen, Y.G., He, Y., Ye, W.M., Lin, C.H., Zang, X.F., Ye, B. (2012). Removal of chromium (III) from aqueous solutions by adsorption on bentonite from Gaomiaozi, China. Environmental Earth Science, 67(1): 1261-1268. https://doi.org/10.1007/s12665-012-1569-3

\section{NOMENCLATURE}

b Affinity parameter of Langmuir (L/mg)

$\mathrm{B}_{\mathrm{T}} \quad$ Variation of adsorption energy $\left(\mathrm{J} . \mathrm{mol}^{-1} \cdot \mathrm{g} \cdot \mathrm{mg}^{-1}\right)$

$C_{0} \quad$ Initial solute concentration $(\mathrm{mg} / \mathrm{L})$

$C_{e} \quad$ Concentration of solute at time $\mathrm{t}(\mathrm{mg} / \mathrm{L})$

$\mathrm{E} \quad$ Elimination rate $(\%)$

$\mathrm{h} \quad$ Initial rate of adsorption(mg/g.min)

$\mathrm{k} \quad$ Freundlich adsorption capacity $(\mathrm{mg} / \mathrm{g})$

$\mathrm{K}_{\mathrm{f}} \quad$ Freundlich constants

$\mathrm{K}_{\mathrm{L}} \quad$ Langmuir adsorption constant (L/mg)

$\mathrm{K}_{\mathrm{T}} \quad$ Equilibrium constant (L. $\mathrm{mg}^{-1}$ )

$\mathrm{K}_{1} \quad$ Rate constant of the pseudo first order adsorption $\left(\mathrm{L} \cdot \mathrm{min}^{-1}\right)$

$\mathrm{K}_{2} \quad$ Second order rate constant of the pseudo-order adsorption $\left(\mathrm{g} \cdot \mathrm{mg}^{-1} \cdot \mathrm{min}^{-1}\right)$

Mass of the adsorbent $(\mathrm{g})$

Freundlich adsorption intensity

Amount of solute adsorbed per unit weight of adsorbent at equilibrium ( $\mathrm{mg} / \mathrm{g}$ )

$\begin{array}{ll}\mathrm{q}_{\mathrm{m}} & \text { Maximum capacity }(\mathrm{mg} / \mathrm{g}) \\ q_{t} & \text { Amount adsorbed at time } \mathrm{t}(\mathrm{mg} / \mathrm{g})\end{array}$

$\mathrm{R} \quad$ Elimination rate $(\%)$

$\mathrm{R}_{\mathrm{L}} \quad$ Separation factor

$\mathrm{R}^{2} \quad$ Correlation coefficient

$\mathrm{t} \quad$ Time $(\mathrm{mn})$

$V \quad$ Volume of the solution (L) 